\title{
Utility-Scale Solar PV in South Carolina: Analysis of Suitable Lands and Geographical Potential
}

\author{
Amanda Farthing ${ }^{1} \cdot$ Michael Carbajales-Dale ${ }^{2} \cdot$ Scott $_{\text {Mason }}^{3} \cdot$ \\ Patricia Carbajales-Dale ${ }^{4} \cdot$ Palak Matta $^{4}$
}

Received: 27 April 2016/Accepted: 18 August 2016/Published online: 15 September 2016

(C) Springer International Publishing Switzerland 2016

\begin{abstract}
The purpose of this study is to determine prospective locations for the implementation of utilityscale solar photovoltaic (PV) technologies and the associated geographical potential of solar energy in South Carolina. By considering limitations imposed by land use, land type, protected areas, and topography, the absolute solar potential was restricted to areas physically, socially, and environmentally favorable for utility PV projects. Using a geographical information system-based suitability model, lands were ranked from 0 (unsuitable for development) to 100 (most suitable). The available solar resource was then calculated for lands with suitability values of at least 50 , 70 , and 90, with contiguous area requirements of 0.18 and $0.036 \mathrm{~km}^{2}$ (consistent with approximately $5 \mathrm{MW}_{\mathrm{AC}}$ and 1 $\mathrm{MW}_{\mathrm{AC}}$ capacity systems, respectively). The results indicate that, with a $5 \mathrm{MW}_{\mathrm{AC}}$ capacity requirement, $3253 \mathrm{~km}^{2}$ (approximately $4.2 \%$ of state land area) obtains the midrange suitability value of 70 . These lands annually receive $5460 \mathrm{TWh}$ of energy from the sun. The analysis and results
\end{abstract}

Amanda Farthing

adfarth@g.clemson.edu

1 Industrial Engineering, Clemson University, 110 Freeman Hall, Clemson, SC 29634, USA

2 Environmental Engineering and Earth Sciences, Clemson University, Clemson, SC 29634, USA

3 Industrial Engineering, Clemson University, 273 Freeman Hall, Clemson, SC 29634, USA

4 Clemson Center for Geospatial Technologies, Clemson University, Clemson, SC, USA can facilitate the identification of potential land areas for implementation of utility-scale solar development and demonstrate the maximum solar flux extractable on these lands.

Keywords Suitability analysis · Photovoltaics . Geographical potential · Solar resource $\cdot$ Land-use planning $\cdot$ Renewable energy potential

\section{Introduction}

The U.S. solar industry, practically non-existent before the year 2000, has experienced tremendous growth in the past decade. Between 2006 and 2015, the annual net generation from solar PV and thermal facilities grew from approximately $508 \mathrm{MWh}$ to $38,614 \mathrm{MWh}$ (EIA 2016). Of the total installed solar capacity, utility-scale PV systems constitute the largest majority and have the highest potential for further developments (Bolinger and Seel 2015). Lopez et al. (2012), for example, estimated that rural, utility-scale PV has a technical capacity potential of $153,000 \mathrm{GW}$, more than 24,500 times current US installed capacity of 6236 $\mathrm{MW}_{\mathrm{AC}}$ (Bolinger and Seel 2015). Of this technical potential, Jacobson et al. (2015) calculates that $2326 \mathrm{GW}$ of solar PV (covering a land area footprint of $17,383 \mathrm{~km}^{2}$ ) could contribute to a $100 \%$ clean energy society by 2050 . Considering the solar industry's large potential for continued expansion, it is increasingly critical to identify land areas that maximize resource potential while minimizing environmental and social conflict. Due to its current market dominance and bourgeoning technical potential, this study focuses specifically on identifying suitable areas and the associated resource potential of utility-scale solar PV, using the state of South Carolina as an example. 
In South Carolina, a lack of political momentum ${ }^{1}$ coupled with restrictive utility company business models has limited the state from experiencing the growth of solar development seen in the rest of the country. Though Jacobson et al. (2015) estimates that $6.7 \mathrm{GW}$ of utility PV could enable South Carolina to meet 2050 end-use loads with $100 \%$ clean energy, at the time of this writing, the state has just $0.25 \%$ (17 MW) of this installed solar capacity (SEIA 2016). Current state policies, such as a renewable portfolio standard of just $2 \%$ of electric utilities' installed nameplate generation capacity by the year 2021 (Bill 1189 2014), are inadequate to facilitate expansion of solar development. However, in light of agreements such as the 2015 Paris Agreement, in which the USA pledged to reduce greenhouse emissions by 26-28\% below 2005 levels by 2025, it can be expected that increased priority will be given to renewable energy developments such as solar across the USA (U.S. Cover Note 2015; EPA 2015).

With the anticipation of increased solar developments, the question remains as to where these developments should take place. In this study, we use geospatial land use, slope, aspect, and solar data to proactively identify lowconflict and topographically suitable areas for the development of utility-scale solar PV in South Carolina, and quantify the solar resource available on these lands. The maps presented here can inform projects that minimize environmental damage and decrease development costs. The associated calculations of geographical potential can serve as an initial gauge of possible progress toward high shares of renewables and national and state emissions targets.

\section{Background}

In order to facilitate the increased deployment of solar technologies, a realistic assessment of the available solar resource and suitable lands is needed. Assessments of the potential of energy sources can be defined in many ways, depending on the considered parameters and constraints. Several of the most common, based on categories utilized by Hoogwijk (2004), include theoretical, geographical, technical, and economic potentials. For solar, the theoretical potential represents the natural upper limit of the solar energy flux, while the geographical potential is the reduction of this energy flow to areas that are considered suitable and available for production. Technical potential is the reduction of the geographical potential due to system

\footnotetext{
1 The SC Distributed Energy Resource Program Act, signed into law June 2014, provides the first major state incentive for solar installation. However, the law has been criticized for providing an unfair advantage to utility companies, and its success in increasing solar capacity cannot yet be judged.
}

performance losses during conversion to secondary energy sources, and the economic potential is the amount of this energy that can be obtained at competitive cost levels.

Several reports, by Lopez et al. (2012), Black \& Veatch (2012), and La Capra Energy Associates (2007), have quantified the technical potential—which considers system performance along with resource strength-of solar PV in South Carolina, whereas our study focuses on the geographical potential. Other sources, such as the Eastern Interconnection States' Planning Council (EISPC) Energy Zones Mapping Tool, provide geospatial data and visualizations of factors influencing solar development (Koritarov et al. 2013). Denholm and Margolis (2007) estimate the per-capita land area needed to supply all end-use electricity with solar PV to be $207 \mathrm{~m}^{2}$ in South Carolina. Our analysis builds upon aspects of these studies in order to provide more specific geospatial data for the siting of solar facilities, and calculations of the exploitable solar resource independent of technological and economic assumptions. ${ }^{2}$

Each of the previously mentioned studies employs unique methodologies and assumptions, with greatly varying results (summarized in Table 1). On one extreme, La Capra and GDS Associates (2007) concluded that deployment of solar power was not feasible in the state, citing inhibitive cost and technological barriers ${ }^{3}$ in their reasoning. A second report, prepared by Black \& Veatch for the South Carolina Energy Advisory Council (2012), calculated the technical potential for utility $\mathrm{PV}$ to be 29,900 MW and generation technical potential to be 39,300 GWh/year. Lopez et al. (2012) determined nearly $32,400 \mathrm{~km}^{2}$ in South Carolina to be suitable for rural, utility-scale PV development, and an associated technical potential of approximately $1500 \mathrm{GW}$, or $2755 \mathrm{TWh} /$ year. As shown in Table 1, each study assumed a differing power density (PD) for solar PV plants, thereby influencing land area, capacity, and generation potential estimates. These three studies demonstrate the large variance in estimates for solar electricity output in South Carolina, as a result of differing assumptions about technical efficiencies, solar resource availability, and land-use suitability.

The EISPC EZ Mapping Tool enables the visualization of areas suitable for utility-scale solar PV by allowing stakeholders to select minimum allowable thresholds for resource quality and other ecological, topographical, technical, and social criteria. Suitability models are

\footnotetext{
$\overline{2}$ It should be noted that our study indirectly incorporates a technical assumption in the application of a minimum contiguous land area requirement for utility-scale solar (see Methodology, Application of Minimum Land Area Requirement).

3 The La Capra (2007) study assumed a net energy conversion efficiency of $10 \%$ for PV systems. However, contemporary commercial wafer-based silicon modules now have efficiencies near $15 \%$ (many are up around $20 \%$ ).
} 
Table 1 Summary of relevant findings and parameters from several analyses of solar potential in South Carolina

\begin{tabular}{|c|c|c|c|c|}
\hline Report title & $\begin{array}{l}\text { US renewable energy technical } \\
\text { potentials: a GIS-based analysis }\end{array}$ & South Carolina resource study & $\begin{array}{l}\text { Analysis of renewable } \\
\text { energy potential in } \\
\text { South Carolina }\end{array}$ & $\begin{array}{l}\text { Energy zones mapping } \\
\text { tool }^{\mathrm{c}}\end{array}$ \\
\hline $\begin{array}{l}\text { Institution/ } \\
\text { Author } \\
\text { (Year) }\end{array}$ & Lopez et al. (2012) & Black \& Veatch (2012) & $\begin{array}{l}\text { La Capra Energy } \\
\text { Associates and GDS } \\
\text { Associates (2007) }\end{array}$ & $\begin{array}{l}\text { Eastern Interconnection } \\
\text { States' Planning } \\
\text { Council (2013) }\end{array}$ \\
\hline $\begin{array}{l}\text { Total potential } \\
\text { land area }(\% \\
\text { state land) }\end{array}$ & $32,399 \mathrm{~km}^{2}(42 \%)$ & $16,887 \mathrm{~km}^{2}(22 \%)$ & N/A & $27,000 \mathrm{~km}^{2}(35 \%)$ \\
\hline $\begin{array}{l}\text { Capacity } \\
\text { potential } \\
(\mathrm{GW})\end{array}$ & 1555 & 29.9 & Infeasible & N/A \\
\hline $\begin{array}{l}\text { Generation } \\
\text { potential } \\
\text { (TWh/year) }\end{array}$ & 2755 & 39.3 & N/A & N/A \\
\hline $\begin{array}{l}\text { Main technical } \\
\text { and } \\
\text { economic } \\
\text { assumptions }^{\text {b }}\end{array}$ & $\begin{array}{l}\mathrm{PD}=48 \mathrm{MW} / \mathrm{km}^{2}, \mathrm{CF}=0.202 \\
\mathrm{MCLA}=1-\mathrm{km}^{2}\end{array}$ & $\begin{array}{l}\mathrm{PD}=35 \mathrm{MW} / \mathrm{km}^{2}, \mathrm{CF}=0.15 \\
\mathrm{MCR}=1 \mathrm{MW}\end{array}$ & $\begin{array}{l}\mathrm{PD}=24.7 \mathrm{MW} / \mathrm{km}^{2} \\
\mathrm{CF}=0.19-0.20 \\
\mathrm{MCR}=1-10 \mathrm{MW} \\
\mathrm{CE}=10 \% \\
\mathrm{LC}=\$ 164-\$ 309 / \\
\mathrm{MWh} \\
\mathrm{AIC}=\$ 4000 / \mathrm{kW}\end{array}$ & N/A \\
\hline $\begin{array}{l}\text { Included or } \\
\text { excluded } \\
\text { land } \\
\text { categories }\end{array}$ & $\begin{array}{l}\text { Excluded: slopes }>=3 \% \text {, } \\
\text { federally protected lands, } \\
\text { inventoried roadless areas, areas } \\
\text { of critical environmental concern }\end{array}$ & $\begin{array}{l}\text { Included (percent assumed } \\
\text { available): pasture/hay }(5 \%) \text {, } \\
\text { row crops }(5 \%) \text {, and quarries/ } \\
\text { strip mines/gravel pits }(10 \%)\end{array}$ & N/A & $\begin{array}{l}\text { Excluded: Open water, } \\
\text { perennial snow/ice, } \\
\text { developed open space, } \\
\text { slopes }>=11 \% \text { d }\end{array}$ \\
\hline
\end{tabular}

Some caution is needed when directly comparing the above results; this table is not a comprehensive summary of the various methodologies and assumptions applied in these studies

${ }^{a}$ Values in this table are associated with an analysis of rural, not urban, utility-scale PV

b Assumption abbreviations: $P D$ Power density, $C F$ capacity factor, $M C L A$ minimum contiguous land area requirement, $C E$ PV system net energy conversion efficiency, $M C R$ minimum capacity requirement, $L C$ Levelized Cost, AIC Average Installed Cost

${ }^{c}$ Land area results calculated for areas with overall suitability value of at least 50

${ }^{\mathrm{d}}$ Refer to page A-23 of report for detailed land suitability values

produced by the weighted overlay of input layers depicting land attributes, each layer with suitability values ranging from 0 (unsuitable) to 100 (best suitability). The suitability values determined for utility-scale solar are detailed by Koritarov et al. (2013). A report generated for utility-scale PV in South Carolina, using the default suitability values, shows that $35 \%$ of state land, or approximately $27,000 \mathrm{~km}^{2}$, has a suitability value of at least 50 . Approximately $1200 \mathrm{~km}^{2}$, or $1.5 \%$ of South Carolina land area, has a value of at least 70 , and no land area obtains a value of 90 or above. The tool does not identify specific potential areas for development or provide estimates of resource potential, as we do.

Our analysis provides a source for comparison to these past results and addresses several perceived limitations of previous assessments of the potential for utility-scale PV in South Carolina. Primarily, the study does not make assumptions about the efficiency of PV technologies (with the exception of a minimum land area requirement) or state-specific capacity factors. Our results, therefore, correspond with a geographical, as opposed to theoretical, technical, or economic potential for solar. As done in previous studies, several land-use types were deemed to be unsuitable for utility PV and thus excluded from this analysis (Lopez et al. 2012, Black \& Veatch 2012). However, similar to Koritarov et al. (2013), a suitability analysis approach was subsequently employed by weighting the remaining lands based on their land type and use, slope, and aspect values. This allowed for consideration of land types not considered by Black \& Veatch (e.g., deciduous forest and cultivated crop areas), as well as greater granularity in the suitability of remaining land areas than that applied by Lopez et al. (2012), which treated all un-eliminated land areas equally. Furthermore, we use global horizontal irradiance (GHI) data to calculate the energy flux on suitable lands, as opposed to assuming either a 
uniform, state-wide capacity factor or land-use requirement, to calculate solar potential.

The identification of lands that are geographically promising without being socially or environmentally contentious should facilitate the implementation of solar projects in South Carolina. A similar process in Nevada, in which the Bureau of Land Management developed the Western Solar Plan with 19 designated Solar Energy Zones (SEZ), has successfully contributed to the lowest power purchase agreement between a utility and solar company in the USA, at just $\$ 0.0384$ per kWh (after an investment tax credit of $30 \%$ ) of electricity produced ${ }^{4}$ (PUCN 2015). The establishment of SEZs has also allowed for a more efficient permitting process, reducing the waiting time from over 2 years to just 10 months. The results shown in our report can facilitate the development of a similar plan for South Carolina.

\section{Methodology}

A GIS-based, suitability analysis was used to determine which South Carolina lands hold the greatest potential for the development of utility-scale solar PV systems. GHI data was then used to quantify the annual solar energy available on these lands. Through the assignment of suitability values to land attributes and weighted combination of layers, this process inherently involved a quantification of social and environmental factors that influence the suitability of land for utility-scale solar PV. These assumptions greatly affect the results of the suitability study and have therefore been detailed. The process was divided into the following steps:

1. Data preparation

2. Creation of analysis mask

3. Identification and reclassification of relevant land attributes

4. Weighting of attributes and combination into suitability layer

5. Calculation of geographical potential at minimum suitability values

6. Application of minimum land area requirement

The full Model Builder process used to perform this analysis in ArcGIS can be found in Fig. 6 in the Appendix. Although ArcGIS was used for this analysis, the general methodology employed here can be applied using any appropriate geospatial program for any region, provided data are available.

\footnotetext{
4 This 20-year, fixed-escalator price includes the present-day investment tax credit of $30 \%$ on the total cost of the solar system.
}

\section{Data Preparation}

Many factors influence a specific land parcel's suitability for utility-scale solar development. We considered: (1) land use, including protected natural environments, parks, and urban areas; (2) the type of land cover; (3) land slope and aspect; and (4) solar irradiation. Table 2 details the sources and file types of the data used.

The Universal Transverse Mercator (UTM) system divides the globe into 60 north and south zones, each spanning $6^{\circ}$ of longitude. This coordinate system uses the cylindrical Transverse Mercator projection. The state of South Carolina lies entirely in Zone 17 of this projection. The coordinate system Clarke 1866 UTM Zone $17 \mathrm{~N}$ with Transverse Mercator projection was used for the data because it has minimal distortion of area and shape. In order to ensure all layers were properly overlaid, added datasets were projected in this coordinate system in ArcGIS.

\section{Creation of Analysis Mask}

As detailed by Patton et al. (2013), utility-scale solar development can have adverse impacts related to land use; ecological resources; air, soil, and water quality; esthetics; cultural resources; and hazardous waste, all of which can be minimized by intelligent site selection. In our study, therefore, solar development was excluded on several land types, including urban areas; national, county, state, regional, and local parks; airports; national forests; historic sites; national wildlife refuges; wilderness areas; and protected marine environments. The corresponding datasets used are shown in Table 2, and specific land areas selected for elimination from the U.S. National Atlas Federal and Indian Land Areas layer can be found in the Appendix, Table 8. The five datasets were merged into a "No Build Zone" shown in Fig. 1, in which solar development was not considered. ${ }^{5}$

This layer was excluded from the South Carolina analysis area to create a resulting analysis mask, which excludes areas upon which, for social and environmental reasons, it has been deemed to be infeasible to build utilityscale solar PV systems. Of the remaining land, clearly some will be more desirable for solar development. The next steps detail the suitability analysis used to make this determination.

\footnotetext{
5 Note: Because this data was available as vector files, the creation of an analysis mask was used as an alternative to reclassifying the layers with 0 suitability, as is done with several attributes of the land use, slope, and aspect raster files in Sect. 2 of the methodology.
} 
Table 2 Data type, source, and file type of data used in geospatial analysis using ArcGIS

\begin{tabular}{lll}
\hline Data & Source & File type \\
\hline State Boundary & ArcGIS Data and Maps & Polygon \\
Land Cover & U.S. Geological Survey (Homer et al. 2015) & Raster \\
Statewide Digital Elevation Model (DEM) for SC & SC Department of Natural Resources (2006) & Raster \\
Urban areas & ArcGIS Data and Maps & Polygon \\
U.S Parks (national, county, state, regional, local) & ArcGIS Data and Maps & Polygon \\
Airport areas & ArcGIS Data and Maps & Polygon \\
Protected Marine Environment & ArcGIS Data and Maps & Polygon \\
U.S. National Atlas Federal and Indian Land Areas & ArcGIS Database & Polygon \\
Global Horizontal Irradiance (10 km resolution) 1998 to 2009 & National Renewable Energy Laboratory (2012a) &
\end{tabular}

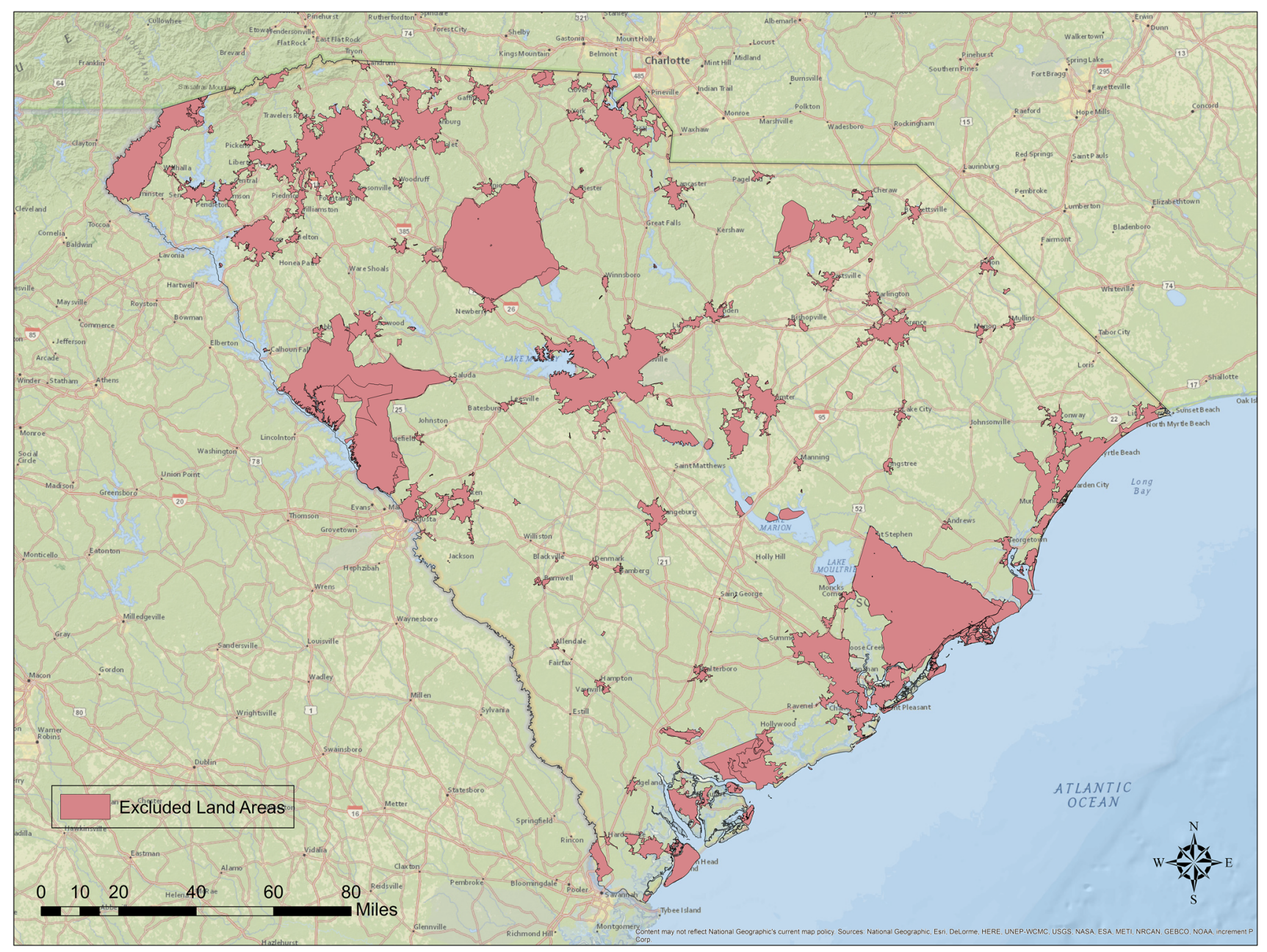

Fig. 1 South Carolina land areas excluded from consideration for the development of utility-scale solar PV facilities

\section{Identification and Reclassification of Relevant Land Attributes}

Physical, site-specific land attributes have a significant impact on the success of a large-scale solar project. The variables that we considered were land use, slope, and aspect. In order to compare and utilize the impact of these factors, the data in each layer were reclassified to a common scale of 0 (unsuitable for utility-scale PV) to 100 (most suitable) using the methodology detailed in this section. The suitability values assigned in this analysis relate to their influence on strength of solar resource, cost 
of development, and the social and environmental feasibility of development.

\section{Land Use}

Land cover data were obtained from the U.S. Geological Survey (USGS) Land Cover Institute (LCI) (Homer et al. 2015). The USGS survey classified lands into the 17 categories shown in Table 3. Land Cover Class Definitions can be referred to for full descriptions of these land types (USGS Land Cover Institute 2012). Land types were assigned reclassification values based on the default suitability criteria used by EISPC in the EZ Mapping Tool, utility-scale PV suitability model (Koritarov et al. 2013). The values indicate the relative physical, economic, and environmental feasibility of installing utility-scale PV on each respective land type. For example, developing PV on woody or herbaceous wetlands (suitability value of 5), which are saturated in water and provide environmental benefits such as flood protection and wildlife habitat, would likely result in greater construction and maintenance costs and environmental degradation than on developed areas of low intensity (suitability value of 50). It should be noted that in present day, land classified as hay/pasture and cultivated crops are appealing to solar developers (suitability values of 80 and 70, respectively) for their expansive flatness and lack of tree cover. In North Carolina, for example, farmers leased approximately $28.3 \mathrm{~km}^{2}$ of pasture and cropland to solar developers between 2013 and 2016 (Ryan 2016). Furthermore, the potential for co-

Table 3 Land use types and assigned suitability values Source Koritarov et al. (2013)

\begin{tabular}{lc}
\hline Category & Suitability value \\
\hline Unclassified & 100 \\
Open water & 0 \\
Perennial snow/ice & 0 \\
Developed, open space & 0 \\
Developed, low intensity & 50 \\
Developed, medium intensity & 15 \\
Developed, high intensity & 10 \\
Barren land & 100 \\
Deciduous forest & 20 \\
Evergreen forest & 10 \\
Mixed forest & 10 \\
Shrub/scrub & 25 \\
Herbaceous & 10 \\
Hay/pasture & 80 \\
Cultivated crops & 70 \\
Woody wetlands & 5 \\
Emergent herbaceous wetlands & 5 \\
\hline
\end{tabular}

development exists, meaning that the high suitability value does not necessarily indicate that the entire area, but rather selected sites, can be used to deploy solar. However, as agricultural land requirements increase to satisfy the needs of a burgeoning global population, the suitability values assigned to areas classified as hay/pasture (80) and cultivated crops (70) may need to be revisited. This model's flexibility allows for such adjustments. The resulting map, showing reclassified land-use values, can be found in Fig. 2 at the end of this section.

\section{Slope and Aspect}

Slope and aspect layers were derived in ArcGIS from the statewide Digital Elevation Model (DEM) for South Carolina and were reclassified based on their suitability for utility-scale solar PV development. The designation of these values is explained here.

Slope In general, "relatively level" slopes ( 1-3\%) are preferred for utility-scale PV development, as they receive greater solar radiation and require lower installation costs (Mancini 2008). However, different mounting systems and installation techniques can allow for successful installations on steeper slopes. ${ }^{6}$ Furthermore, analyzing the data collected by a USDA Forest Service study shows that at latitude of $30^{\circ}$ North (that of South Carolina), solar resource is not significantly depleted until slope increases to greater than $30^{\circ}$ (Buffo et al. 1972). Considering these varying reports and the fact that our study is not specific to one particular PV technology or mounting system, the reclassification values in Table 4 were determined. Note that the slope values considered acceptable for utility-scale solar are greater than those considered in the previously mentioned Lopez et al. (2012) and EISPC studies (Koritarov et al. 2013). Figure 2 depicts the resulting map layer with reclassified slope values.

Aspect Aspect is the compass direction that a slope faces. In the Northern Hemisphere, south-facing slopes receive the greatest amount or solar radiation, and north-facing receive the least. As shown in Table 5, aspect values were first modeled with a horizontally shifted cosine curve, to place aspects of $180^{\circ}$ at the highest point on the curve, then normalized and scaled to range from 0 to 100 .

\footnotetext{
${ }^{6}$ The company Schletter Inc, for instance, advertises that their GYAK hydraulic ram can install mounting systems on slopes up to $20^{\circ}$.
} 
Table 4 Reclassification of land slope with assigned suitability values

\begin{tabular}{lc}
\hline Slope $\left(^{\circ}\right)$ & Suitability values \\
\hline 0 & 100 \\
1 & 100 \\
2 & 95 \\
3 & 90 \\
4 & 80 \\
5 & 70 \\
6 & 55 \\
7 & 35 \\
8 & 20 \\
9 & 10 \\
10 & 0 \\
$>11$ & 0 \\
\hline
\end{tabular}

\section{Weighting of Attributes and Combination into Suitability Layer}

Once all three datasets were reclassified to a common scale of $0-100$, layers were weighted based on their relative importance to site selection and combined to produce a suitability layer. Each $30 \mathrm{~m}$ by $30 \mathrm{~m}$ land parcel in the resulting layer has a suitability value for utility-scale solar PV development ranging from 0 (unsuitable) to 100 (most suitable). The resulting suitability value indicates the relative confidence with which a particular land area can be used to deploy utility-scale solar PV, considering the land use, slope, and aspect attributes of the area.

Land use was considered to be the most important factor in selecting a site for utility-scale solar development due to its relatively large influence on the social, environmental, and economic impacts of development (Patton et al. 2013), as well as the feasibility of permit acquisition. ${ }^{7}$ Aspect and slope were considered the second and third most influential factors, respectively. In reality, site-specific available solar energy is a complex function of slope, aspect, and other factors, as exemplified by Chandrakar and Tiwari (2013). The weighting shown in Eq. 1 simplifies this relationship, but maintains a slightly larger influence of aspect, as is it is well-established that in the northern hemisphere southfacing orientation is optimal for maximizing solar irradiance, while "no definite value is given by researchers for the optimum tilt angle" (Chandrakar and Tiwari 2013) and current mounting systems allow for slight correction of unfavorable slopes. The weighting factors are given in Eq. 1:

Suitability $=0.70 \cdot$ land use $+0.20 \cdot$ aspect $+0.10 \cdot$ slope

The distribution of the resulting suitability values for South Carolina is shown in Fig. 3. In ArcGIS, one suitability value was calculated for each $900-\mathrm{m}^{2}$ section of a grid overlaying the state.

In order to illustrate the results' sensitivity to the applied minimum suitability value, areas with suitability values over 50, 70 and 90 on a scale of $0-100$ were analyzed separately for their geographical solar potential.

\section{Calculation of Geographical Potential at Minimum Suitability Values}

\section{Solar Irradiance Data}

The availability of solar resource is one of the most important considerations for a potential solar PV development. Solar resource can be quantified in several ways: direct normal irradiation, diffuse horizontal irradiation, or global horizontal irradiation. We used GHI data, as it includes both the direct and diffuse components of solar radiation, both of which can be utilized by solar PV systems. As shown in Fig. 4, the average annual GHI in South Carolina ranges from 4.34 to $4.89 \mathrm{kWh} / \mathrm{m}^{2} /$ day. Considering that utility-scale PV systems have been installed in areas in the Northeastern United States with much lower solar resource, ${ }^{8}$ all values in South Carolina are sufficient for the development of utility PV systems, and no land areas need be excluded due to limited solar resource.

\section{Solar Resource Calculations}

Using GHI data provided by NREL (2012a, b), the annual terawatt hours (TWh/year) of solar energy available for utility-scale solar PV development on suitable lands was calculated. This was accomplished by multiplying the solar resource layer by a binary suitable land layer (with values of 1 where suitability values are above the selected minimum and 0 elsewhere), as shown in Eq. (2). The geographical potential was calculated at three minimum suitability rankings: 50, 70, and 90 .

\footnotetext{
8 According to NREL's Solar Prospector Tool (2012b), New Jersey and New York receive an annual average GHI of approximately $3.5-4.5 \mathrm{kWh} / \mathrm{m}^{2} /$ day. As documented in NREL's Open PV Project (2016), these states have, respectively, 1505.98 and $285.82 \mathrm{MW}$ of installed PV capacity.
}

\footnotetext{
${ }^{7}$ Studies, such as that of the Universidad Politécnica de Valencia, quantify the relatively high risk to project developers of social consequences and permitting delays associated with land acquisition-influenced primarily by land use - as compared to system performance losses or plant operation costs, which are associated with a site's slope and aspect (Aragonés-Beltrán et al. 2009).
} 


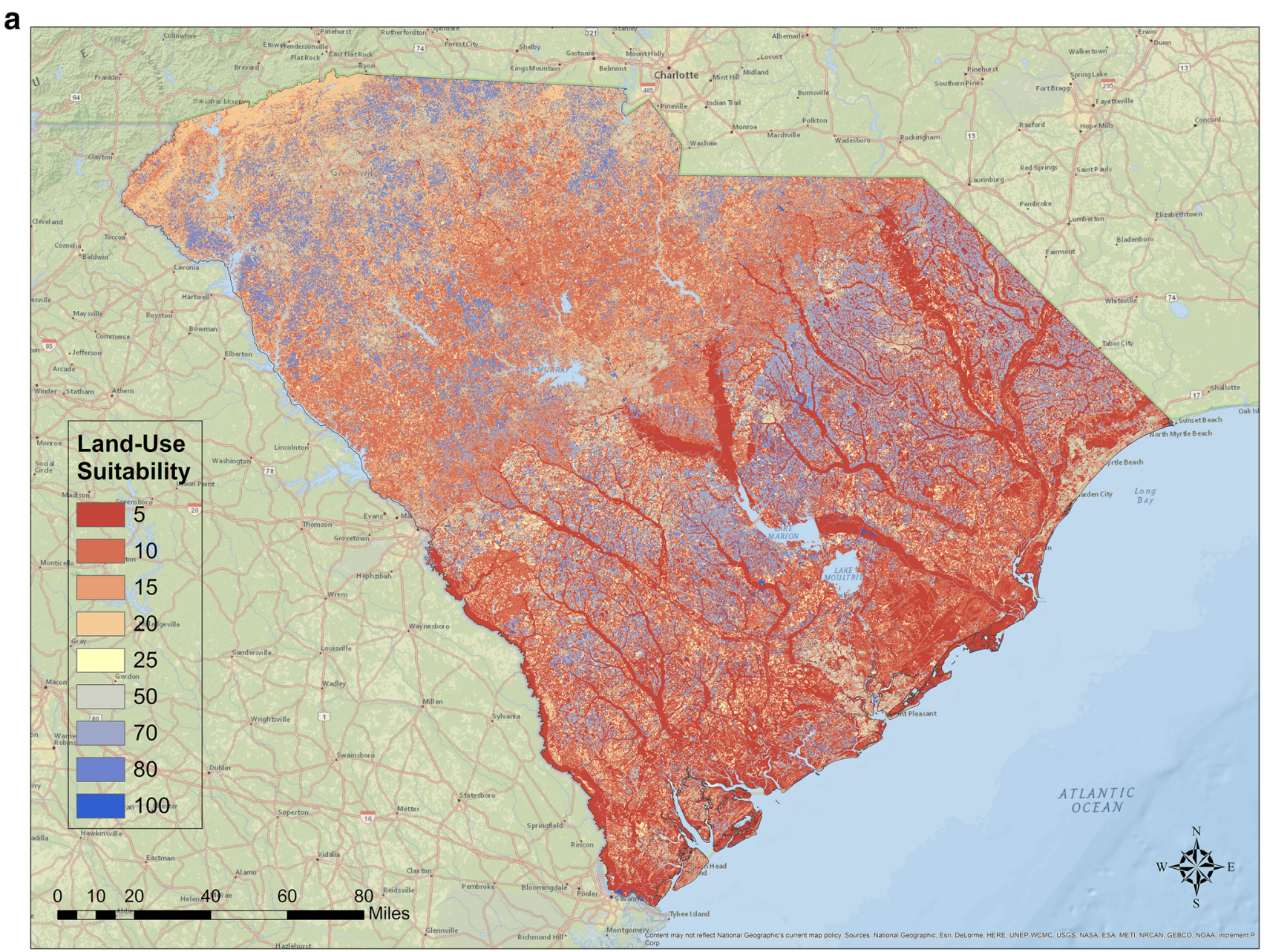

Fig. 2 Reclassified land cover and slope layers for South Carolina

Total annual energy $\left(\frac{\mathrm{TWh}}{\text { year }}\right)=$

State $\sum\left[B \cdot \mathrm{GHI}\left(\frac{\mathrm{kWh}}{\mathrm{m}^{2} \cdot \text { day }}\right) \cdot 365\left(\frac{\text { days }}{\text { year }}\right)\right.$

cell area $\left(900 \mathrm{~m}^{2}\right) \cdot$ conversion factor $\left.\left(10^{-9} \frac{\mathrm{TWh}}{\mathrm{kWh}}\right)\right]$

where $B$ is a binary variable such that $B$ equals one if the minimum suitability value is met and zero otherwise.

\section{Application of Minimum Land Area Requirement}

The total annual available solar energy on suitable lands was further restricted based on established definitions of "utility-scale" solar developments. As defined by Bolinger and Weaver (2015), "utility-scale" solar projects are those with nameplate capacities larger than $5 \mathrm{MW}_{\mathrm{AC}}$. The Energy Information Administration (EIA), however, reports utility-scale development data for all projects larger than $1 \mathrm{MW}_{\mathrm{AC}}$ in capacity (Bolinger and Weaver 2015). To analyze the sensitivity of the final geographical solar potential to this minimum capacity requirement, both a 1 $\mathrm{MW}_{\mathrm{AC}}$ and $5 \mathrm{MW}_{\mathrm{AC}}$ minimum were used.

In order to apply this capacity requirement in ArcGIS, approximate equivalent contiguous land areas were needed. The power density, or area required for $1 \mathrm{MW}$ of installed solar capacity, is impacted by technology choices, topography of the site, panel spacing, and intensity of the solar resource. An analysis of utility-scale solar projects in the USA determined a total-area capacity-weighted average for all solar power plants to be $0.036 \mathrm{~km}^{2}$ per $\mathrm{MW}_{\mathrm{AC}}$ (Ong et al. 2013). Therefore, this study used contiguous land areas of approximately 0.18 and $0.036 \mathrm{~km}^{2}$ to satisfy the 5 $\mathrm{MW}_{\mathrm{AC}}$ and $1 \mathrm{MW}_{\mathrm{AC}}$ minimum capacity requirements, respectively. Only contiguous land areas larger than these minimum areas were considered for final potential calculations. 


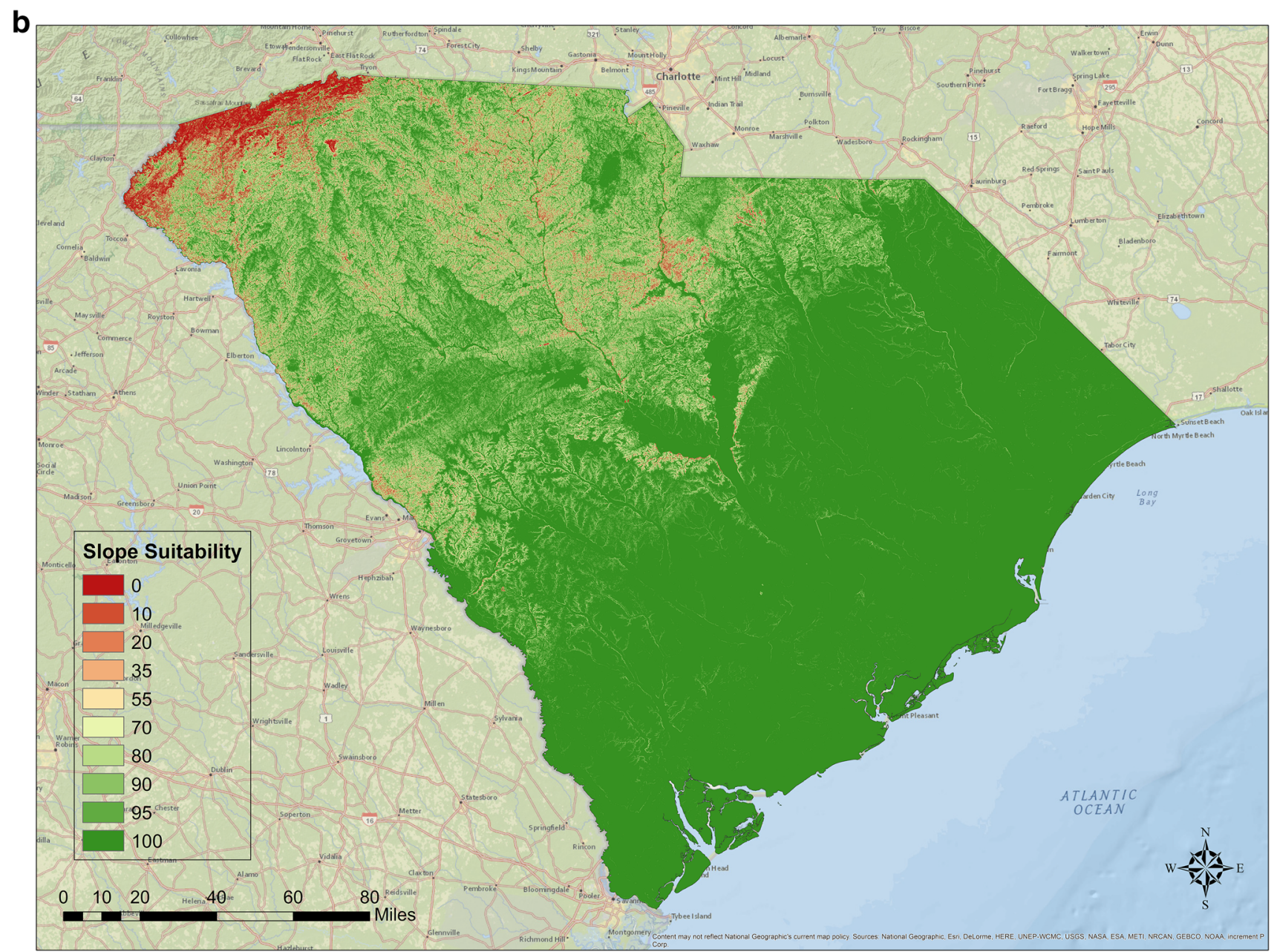

Fig. 2 continued

Table 5 Reclassification of land aspect with assigned suitability values

\begin{tabular}{llcc}
\hline Aspect $\left({ }^{\circ}\right)$ & $\operatorname{Cos}(x+\pi)+1^{\mathrm{a}}$ & Normalized value & Suitability value \\
\hline $342-18$ & 0.00 & 0.00 & 0 \\
$18-54$ & 0.19 & 9.55 & 9 \\
$54-90$ & 0.69 & 34.55 & 34 \\
$90-126$ & 1.31 & 65.45 & 65 \\
$126-162$ & 1.81 & 90.45 & 90 \\
$162-198$ & 2.00 & 100.00 & 100 \\
$198-234$ & 1.81 & 90.45 & 90 \\
$234-270$ & 1.31 & 65.45 & 65 \\
$270-306$ & 0.69 & 34.55 & 34 \\
$306-342$ & 0.19 & 9.55 & 9 \\
\hline
\end{tabular}

${ }^{a}$ Values in this column were calculated using the average of the adjacent aspect range

It should be noted that in light of recent technology improvements, the applied area requirement is conservative. A recently approved Stuttgart Solar project in
Alabama, for example, has a nameplate capacity of $81 \mathrm{MW}$ and will cover approximately 500 acres $\left(0.025 \mathrm{~km}^{2} / \mathrm{MW}\right)$ (APSC 2015). It can be expected that higher solar cell efficiencies will continue to drive down area requirements for utility-scale PV plants. This model can be adapted to account for technology improvements by adjusting the minimum contiguous land area requirement.

\section{Results}

The total annual solar energy available, total qualifying land area, and percentage of state land use are reported along two dimensions: three minimum suitability values and two minimum contiguous land area requirements, for a total of six results in each category. As previously detailed, the suitability values correspond to the relative confidence with which a given land parcel can be used to develop utility-scale solar PV, on a scale of 0-100, given the area's 
Fig. 3 Area and cumulative percent of SC lands with listed suitability values for utilityscale solar PV, calculated for 900- $\mathrm{m}^{2}$ land parcels using a weighted combination of land use, aspect, and slope
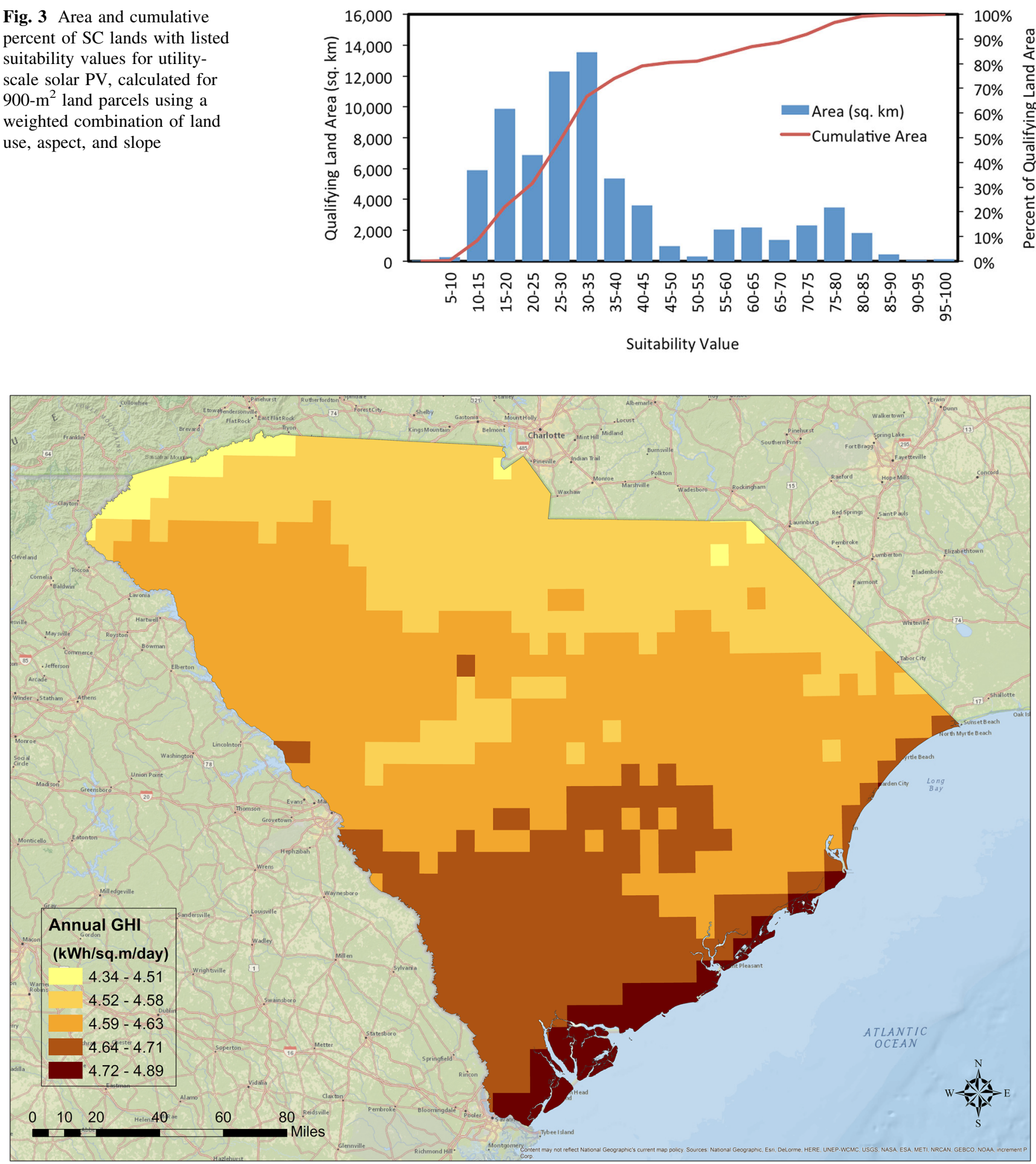

Fig. 4 Solar resource availability in South Carolina, measured as GHI $\left(\mathrm{kWh} / \mathrm{m}^{2} /\right.$ day $)$

slope, aspect, and land type. The minimum contiguous land area requirements of 0.18 and $0.036 \mathrm{~km}^{2}$ correspond to two established definitions of "utility-scale" solar projects- 5 $\mathrm{MW}_{\mathrm{AC}}$ and $1 \mathrm{MW}_{\mathrm{AC}}$, respectively. All results are summarized in Table 6.
Figure 5a depicts contiguous land areas large enough for a $5 \mathrm{MW}_{\mathrm{AC}}$ solar PV development $\left(0.18 \mathrm{~km}^{2}\right)$ at suitability cutoffs of 50,70, and 90, with previously established "No Build Zones" eliminated. The three land areas are overlayed, as those with higher suitability values are simply 
Table 6 Available energy and land use for six suitability scenarios

\begin{tabular}{llllll}
\hline $\begin{array}{l}\text { Minimum suitability } \\
\text { rank }\end{array}$ & $\begin{array}{l}\text { Min } \\
\text { capacity }\end{array}$ & $\begin{array}{l}\text { Minimum contiguous land area } \\
\left(\mathrm{km}^{2}\right)\end{array}$ & $\begin{array}{l}\text { Total annual energy available } \\
(\mathrm{TWh})\end{array}$ & $\begin{array}{l}\text { Land area } \\
\left(\mathrm{km}^{2}\right)\end{array}$ & $\begin{array}{l}\text { State land use } \\
(\%)\end{array}$ \\
\hline 50 & $5 \mathrm{MW}_{\mathrm{AC}}$ & 0.18 & 14,434 & 8600 & 11.1 \\
& $1 \mathrm{MW}_{\mathrm{AC}}$ & 0.036 & 18,699 & 11,143 & 14.3 \\
70 & $5 \mathrm{MW}_{\mathrm{AC}}$ & 0.18 & 5460 & 3253 & 4.2 \\
& $1 \mathrm{MW}_{\mathrm{AC}}$ & 0.036 & 10,168 & 6059 & 7.8 \\
90 & $5 \mathrm{MW}_{\mathrm{AC}}$ & 0.18 & 37 & 22.1 & 0.03 \\
& $1 \mathrm{MW}_{\mathrm{AC}}$ & 0.036 & 107 & 63.6 & 0.08 \\
\hline
\end{tabular}

a

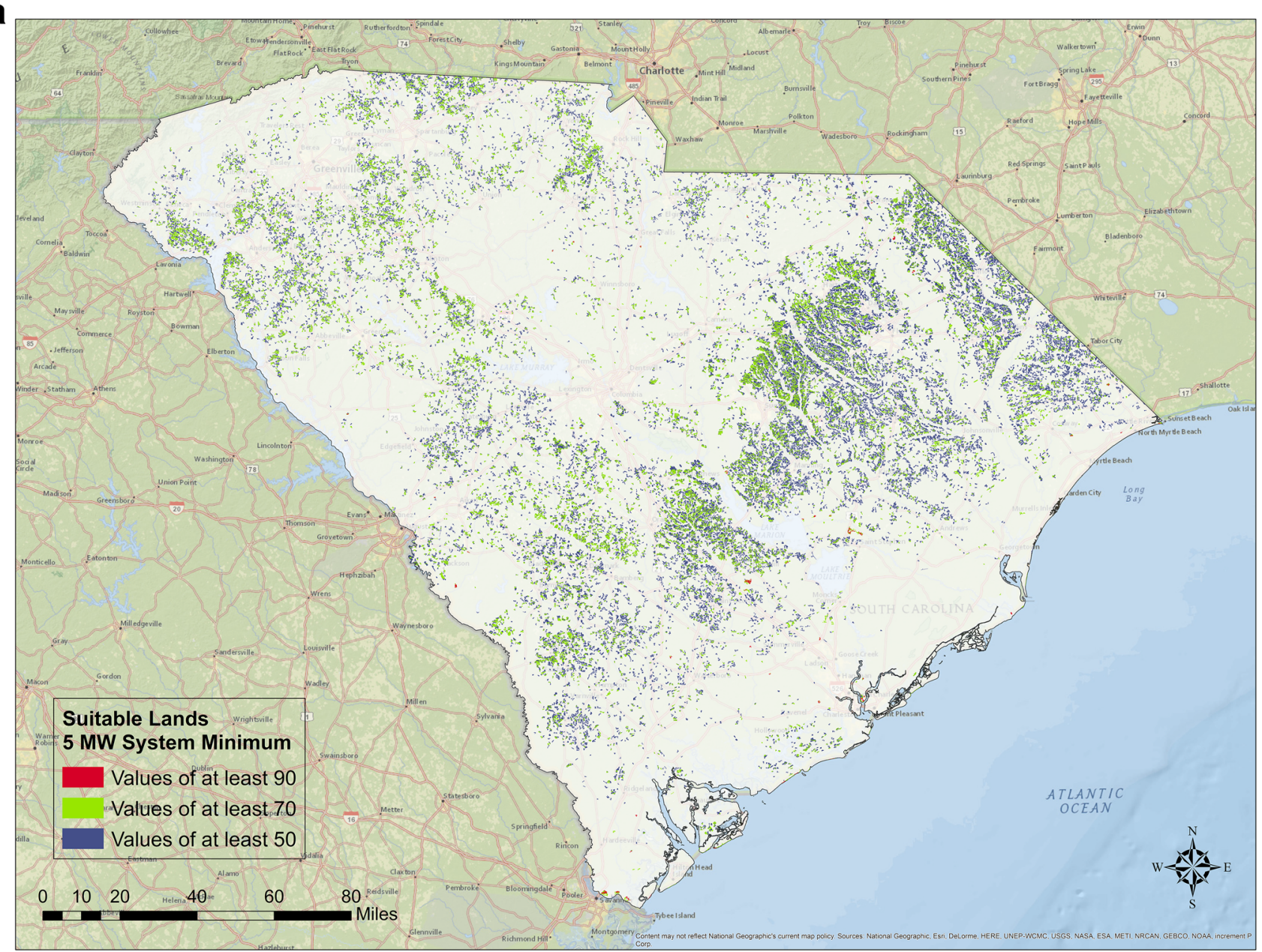

Fig. 5 Land areas with suitability scores of at least 50, 70, and 90 (Note: Land areas with a suitability score of at least 90, though present, are difficult to discern at this resolution), with a minimum capacity requirement of $5 \mathrm{MW}_{\mathrm{AC}}(\mathbf{a})$ and $1 \mathrm{MW}_{\mathrm{AC}}(\mathbf{b})$

restricted portions of those with low suitability cutoffs. Figure $5 \mathrm{~b}$ depicts suitable land areas with an applied 1 $\mathrm{MW}_{\mathrm{AC}}$ capacity $\left(0.036 \mathrm{~km}^{2}\right.$ land area) requirement.

As shown in the final maps (Fig. 5), most suitable land areas are dispersed across almost all of the state, but especially concentrated in the northeast. Most coastal land area is unsuitable for the development for utility-scale solar, likely due to the presence of low-lying wetlands.

\section{Discussion}

The resulting land area values and available solar energy potentials vary greatly depending on the applied minimum capacity and suitability value requirements - ranging from $37 \mathrm{TWh} /$ year on $22 \mathrm{~km}^{2}$ of land to $18,699 \mathrm{TWh} /$ year on $11,143 \mathrm{~km}^{2}$. A mid-range scenario of land with suitability values of at least 70 and an applied $1 \mathrm{MW}_{\mathrm{AC}}$ capacity 


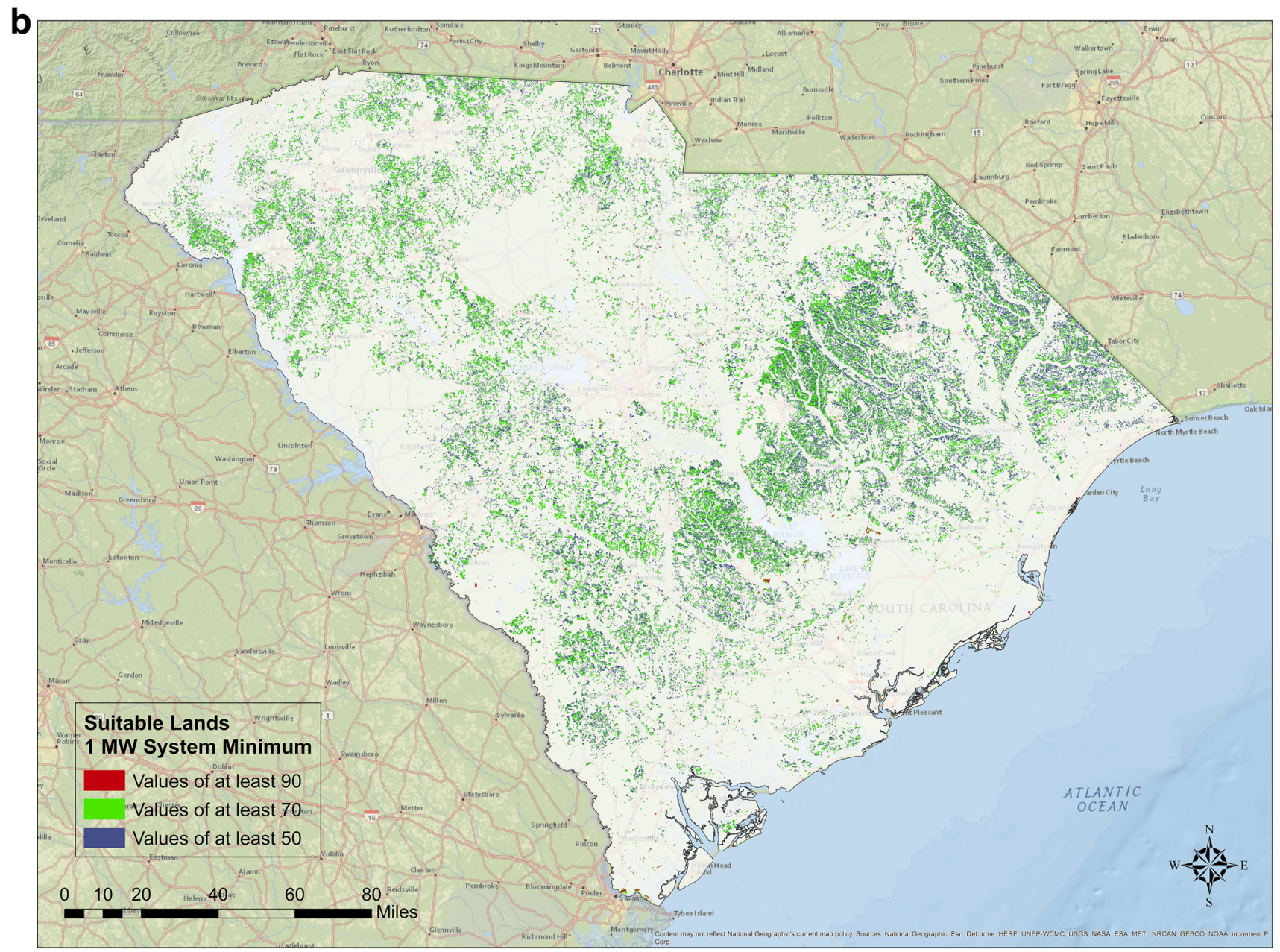

Fig. 5 continued

minimum shows 10,168 TWh/year on $6059 \mathrm{~km}^{2}$ of qualifying land-an area slightly smaller than the state of Delaware. This equates to approximately $1.16 \mathrm{TW}$ of raw capacity. Assuming $15 \%$ module efficiency and a ground cover ratio of 0.4 , this $69.6 \mathrm{GW}$ of solar capacity well exceeds the $6.7 \mathrm{GW}$ estimated by Jacobson et al. (2015) to be needed to contribute to a 2050 clean energy economy in South Carolina. Although very few land areas have suitability values above the most stringent cutoff (suitability value of 90), the analysis of these lands does provide insight as to which land parcels are most preferable and should be considered first by developers for large-scale solar projects. Furthermore, reducing the minimum capacity requirement from $5 \mathrm{MW}_{\mathrm{AC}}$ to $1 \mathrm{MW}_{\mathrm{AC}}$ dramatically increases the amount of qualifying land areas, suggesting that it may be efficacious to implement smaller distributed solar projects to meet load demands.

The EISPC EZ Mapping Tool model run for utility-scale PV reports a considerably greater land area with suitability values of at least $50\left(\sim 27,000 \mathrm{~km}^{2}\right)$, but a smaller area for lands with a minimum suitability value of 70 $\left(\sim 1200 \mathrm{~km}^{2}\right)$, indicating that most land areas in the EISPC model obtained more moderate suitability values than those we have obtained (Koritarov et al. 2013). Areas above a suitability value of 90 in this report $\left(22.1\right.$ and $\left.63.6 \mathrm{~km}^{2}\right)$ are just slightly greater than the $0 \mathrm{~km}^{2}$ obtained by the EISPC model. A complete comparison of these results can be found in Table 7. Differences in these results could be influenced by the fact that the EISPC model considered distance to transmission lines, did not include land aspect, assigned different suitability values and layer weightings to

Table 7 Comparison of suitable land area results to those obtained from EISPC EZ Mapping Tool utility-scale PV model run, at differing minimum suitability values and capacity requirements

\begin{tabular}{llll}
\hline Minimum suitability value & 50 & 70 & 90 \\
\hline EISPC EZ Mapping Tool $\left(\mathrm{km}^{2}\right)$ & 27,000 & 1200 & 0 \\
Our results (1 MW $\mathrm{AC}$ minimum) $\left(\mathrm{km}^{2}\right)$ & 11,143 & 6059 & 63.6 \\
Our results (5 MW $\mathrm{AC}$ minimum) $\left(\mathrm{km}^{2}\right)$ & 8600 & 3253 & 22.1 \\
\hline
\end{tabular}


all layers except land use, and did not include a minimum contiguous area requirement.

The amount of land considered suitable at suitability values of at least 50 and 70 is significantly greater than the area obtained by Black \& Veatch $\left(850 \mathrm{~km}^{2}\right)$, likely due to the fact that our report assigned a range of suitability values to many land types completely excluded by the Black \& Veatch report. Conversely, the land area considered for utility-scale development by Lopez et al. (2012) $\left(32,400 \mathrm{~km}^{2}\right)$ is nearly three-fold greater than the highest estimate reported here $\left(11,143 \mathrm{~km}^{2}\right)$. Although, as in our report, this calculation excluded urban areas and areas of high social and ecological value, it was much less stringent on the consideration of various land types, only excluding water and wetlands, and also did not consider land aspect in its analysis (Lopez et al. 2012).

It is important to note that the assumptions made in this analysis in regard to the reclassification of slope, aspect, and land-use values, as well as the relative importance of these factors in utility-scale PV development, greatly influence the findings. In reality, these factors will have much more complex relationships than are modeled in this study. For instance, on land areas with very steep slopes, the influence of land aspect may be much greater than on shallow slopes. Further study should be done to more accurately determine the interrelatedness of these factors, how to model such relations, and the sensitivity of the results to different weighting schemes.

The results shown in this report can facilitate the implementation of utility-scale solar projects in South Carolina. Considering the potential for mandatory emissions reduction and clean energy requirements in the nearterm, policymakers, utility companies, and solar developers should look to regional planning studies to begin analyzing where technologies such as solar can be best utilized without compromising environmental and societal values.

\section{Conclusions and Next Steps}

We show land areas with the highest resource potential and lowest environmental and social conflict. Using a suitability analysis, which considered land use and type, slope, and aspect, three suitability scenarios were evaluated at two minimum capacity requirements, for a total of six scenarios. These results include the total area of South
Carolina lands with a calculated suitability value of at least 50,70 , and 90 on a scale of $0-100$, as well as the annual amount of solar energy available on these land areas. With a minimum capacity requirement of $5 \mathrm{MW}_{\mathrm{AC}}$, the total area of land that surpasses the most stringent suitability cutoff is $22.1 \mathrm{~km}^{2}$, and $37 \mathrm{TWh} /$ year of solar energy befalls these lands. These areas offer the greatest geographical potential for utility-scale solar projects and should be scrutinized more rigorously for potential developments. With a 1 $\mathrm{MW}_{\mathrm{AC}}$ capacity requirement, the total area of land with suitability values of at least 50 was $11,143 \mathrm{~km}^{2}$, and 18,699 TWh/year of solar energy is theoretically extractable across these areas. All specific land areas are visible in Fig. 5 of this report.

With the exception of the applied minimum contiguous area requirement, which indirectly accounts for module efficiency, factors such as proximity to infrastructure, socio-political influence of government policies, performance parameters of current PV technologies, and financial costs of solar development are not taken into consideration in this analysis of geographical potential. As the energy market evolves and module efficiencies increase, these factors will increasingly influence the technical potential for solar to meet statewide energy needs. This initial study, however, is less dependent on such variable factors and can be used as a starting point to locate specific areas for implementation or further analysis and to demonstrate the maximum solar flux extractable on these lands. Our results should indicate to policymakers that solar offers a viable way for South Carolina to diversify its fuel mix while reducing emissions, and the maps should indicate to potential developers the specific land parcels which will be most efficacious in terms of utility-scale solar power production. The Model Builder process shown in the Appendix allows this same analysis to be run on any chosen land area.

Acknowledgments The authors would like to acknowledge the support of the Clemson Center for Geospatial Technologies for their technical support in the use of ArcGIS throughout the course of this work.

\section{Appendix}

See Table 8; Fig. 6. 
Table 8 South Carolina land areas selected (with Definition Query in ArcGIS) from U.S. National Atlas Federal and Indian Land Areas as No Build Zones

\begin{tabular}{ll}
\hline Feature name & Feature type \\
\hline Francis Marion National Forest & National Forest FS \\
Nantahala National Forest & National Forest FS \\
Sumter National Forest & National Forest FS \\
Ninety-Six National Historic Site & National Historic Site NPS \\
Kings Mountain National Military Park & National Military Park NPS \\
Ace Basin National Wildlife Refuge & National Wildlife Refuge FWS \\
Cape Romain National Wildlife Refuge & National Wildlife Refuge FWS \\
Carolina Sandhills National Wildlife Refuge & National Wildlife Refuge FWS \\
Pinckney Island National Wildlife Refuge & National Wildlife Refuge FWS \\
Santee National Wildlife Refuge & National Wildlife Refuge FWS \\
Savannah National Wildlife Refuge & National Wildlife Refuge FWS \\
Ellicott Rock Wilderness & Wilderness FS \\
Ellicott Rock Wilderness & Wilderness FS \\
Hell Hole Bay Wilderness & Wilderness FS \\
Little Wambaw Swamp Wilderness & Wilderness FS \\
Wambaw Creek Wilderness & Wilderness FS \\
Wambaw Swamp Wilderness & Wilderness FS \\
Cape Romain Wilderness & Wilderness FWS \\
Congaree Swamp National Monument Wilderness & Wilderness NPS \\
\hline
\end{tabular}

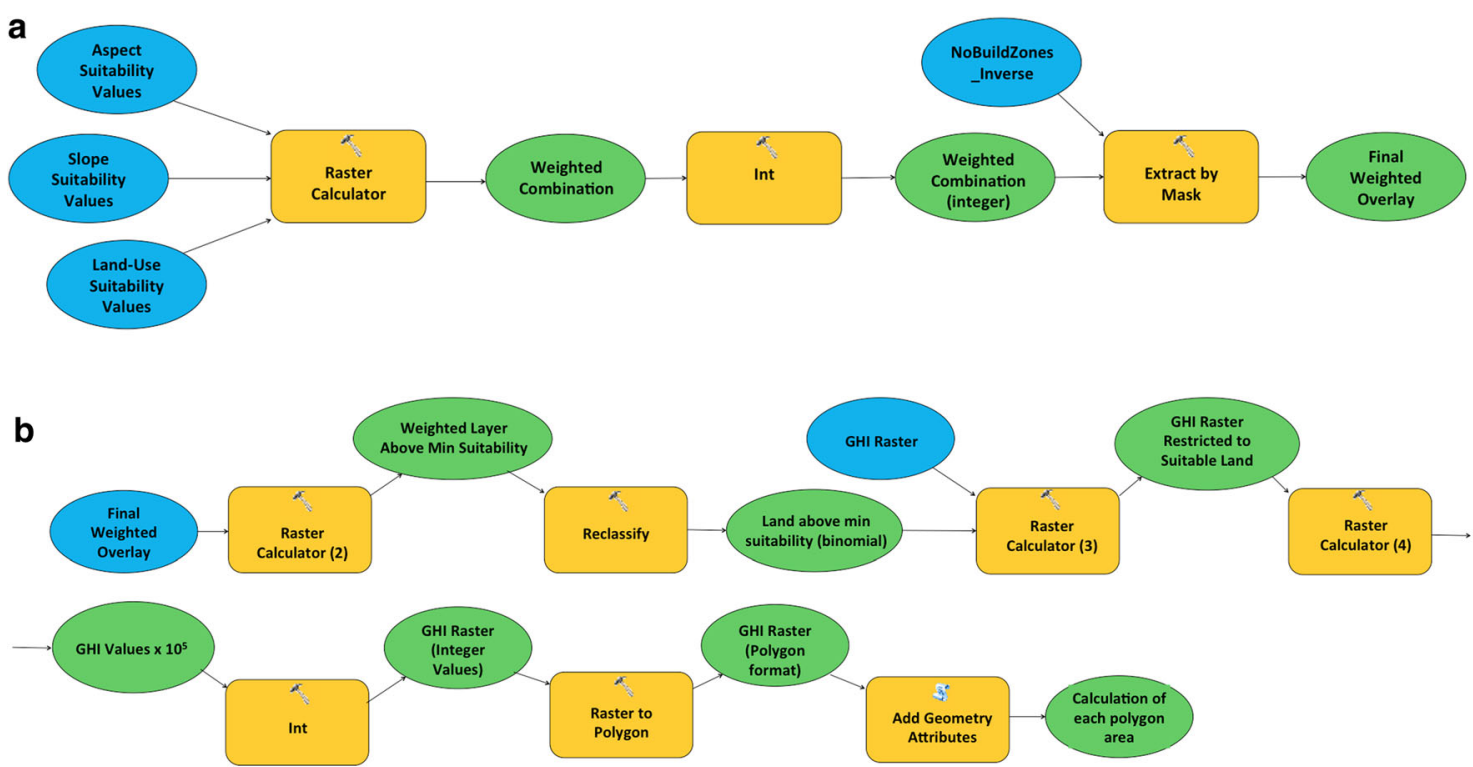

C

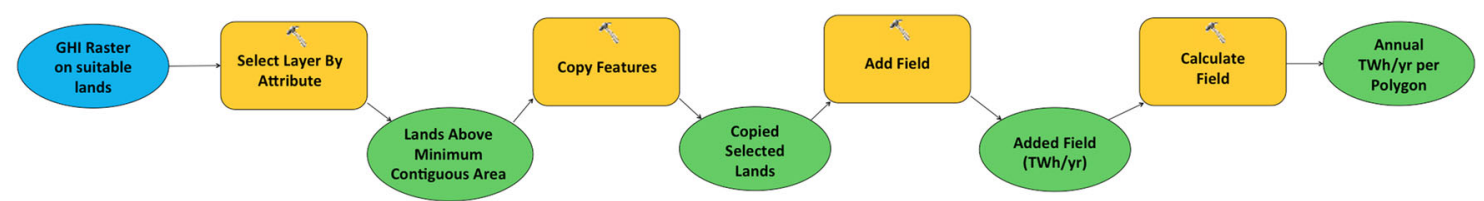

Fig. 6 Model Builder diagram of process used in ArcGIS to a create a weighted combination of reclassified slope, aspect, and land-use values, excluding previously established "No Build Zones," b determine the solar flux on land areas above a minimum suitability value, and the area of each land parcel, and $\mathbf{c}$ select lands above a minimum contiguous land area requirement and calculate the final TWh per year on these lands 


\section{References}

Aragonés-Beltrán P, Pastor-Ferrando J, Chaparro-González F, Poveda Bautista R (2009) Selection of photovoltaic solar power plant projects using ANP. In: Proceedings of the international symposium on the analytic hierarchy process 2009

Arkansas Public Service Commission (APSC) (2015) Docket No 15-014-U. Order No 5. http://www.apscservices.info/pdf/15/15014-u_104_1.pdf. Accessed 4 August 2016

Bill 1189 (2016) South Carolina General Assembly 120th Session, 2013-2014. http://www.scstatehouse.gov/sess120_2013-2014/ prever/1189_20140521.htm. Accessed 26 January 2016

Black \& Veatch (2012) South Carolina Resource Study. http://www. scstatehouse.gov/CommitteeInfo/EnergyAdvisoryCouncil/Resou rceStudyComments/SCEACResourceStudy_FINAL.pdf. Accessed 12 November 2015

Bolinger M, Seel J (2015) Utility-scale solar 2014: an empirical analysis of project cost, performance, and pricing trends in the United States. Lawrence Berkeley National Laboratory. LBNL1000917

Buffo J, Fritschen L, Murphy J (1972) Direct solar radiation on various slopes from 0 to 60 degrees north latitude. USDA Forest Service, Portland, Oregon. http://www.fs.fed.us/pnw/pubs/pnw_ rp142.pdf

Chandrakar A, Tiwari Y (2013) Optimization of Solar power by varying tilt angle/slope. Int $\mathrm{J}$ Emerg Technol Adv Eng 3(4): $145-150$

Denholm P, Margolis R (2007) The regional per-capita solar electric footprint for the United States. National Renewable Energy Laboratory. NREL/TP-670-42463

Environmental Protection Agency (EPA) (2015) Clean Power Plan: State at a Glance South Carolina, 1-2. https://www3.epa.gov/ airquality/cpptoolbox/south-carolina.pdf. Accessed 3 August 2016

Homer CG, Dewitz JA, Yang L, Jin S, Danielson P, Xian G, Coulston J, Herold ND, Wickham JD, Megown K (2015) Completion of the 2011 National Land Cover Database for the conterminous United States-Representing a decade of land cover change information. Photogramm Eng Remote Sens 81(5):345-354

Hoogwijk M (2004) On the global and regional potential of renewable Energy sources. Dissertation, Utrecht University

Jacobson M, Delucchi M, Bazouin G, Bauer Z et al. (2015) $100 \%$ Clean and renewable wind, water, and sunlight (WWS) all-sector energy roadmaps for the 50 United States. Energ Environ Sci 8:2093-2117. doi:10.1039/C5EE01283J

Koritarov V, Kuiper J, Hiava K, Orr A et al. (2013) Energy zones study: a comprehensive web-based mapping tool to identify and analyze clean energy zones in the eastern interconnection. Argonne National Laboratory ANL/DIS-13/09

La Capra Associates Inc. and GDC Associates Inc. (2007) Analysis of Renewable Energy Potential in South Carolina. http://www.
cepci.org/sites/cepci/files/images/PDF/R2.pdf. Accessed 11 November 2015

Lopez A, Roberts B, Heimiller D, Blair N, Porro G (2012) U.S. renewable energy technical potentials: a GIS-based analysis. National Renewable Energy Laboratory Document. NREL/TP6A20-51946

Mancini T (2008) Siting utility-scale solar. Sandia National Laboratories. http://www2.epa.gov/sites/production/files/2014-06/docu ments/lrb2g_mancini.pdf. Accessed 27 January 2016

National Renewable Energy Laboratory (NREL) (2012a) Dynamic maps, GIS data, and analysis tools-solar data. http://www.nrel. gov/gis/data_solar.html. Accessed 17 March 2015

NREL (2012b) Solar prospector Imaps.nrel.gov. http://maps.nrel.gov/ prospector. Accessed 24 April 2015

NREL (2016) The OpenPV Project. https://openpv.nrel.gov/. Accessed 19 August 2015

Ong S, Campbell C, Denholm P, Margolis R, Heath G (2013) Landuse requirements for solar power plants in the United States. National Renewable Energy Laboratory. NREL/TP-6A20-56290

Patton T, Almer L, Hartmann H, Smith K.P (2013) An overview of potential environmental, cultural, and socioeconomic impacts and mitigation measures for utility-scale solar energy development. Argonne National Laboratory ANL/EVS/R-13/5

Public Utilities Commission of Nevada (PUCN) (2015) Original filing. http://pucweb1.state.nv.us/PDF/AxImages/DOCKETS_ 2015_THRU_PRESENT/2015-7/3615.pdf. Accessed 03 August 2016

Ryan J (2016) "Solar Power More Lucrative Than Crops at Some US Farms" Renewable Energy World. http://www.renewableenergy world.com/articles/2016/04/solar-power-more-lucrative-than-cropsat-some-us-farms.html. Accessed 11 August 2016

SC Department of Natural Resources (2006) Statewide DEM for SC. http://www.dnr.sc.gov/GIS/descdem.html. Accessed 15 March 2015

Schletter, Inc. Sunfix Ground Mount. http://www.schletter.us/support/ Ground-Mount-System-Overview.pdf. Accessed 27 July 2016

Solar Energy Industries Association (SEIA) (2016) Solar Spotlight: South Carolina. http://www.seia.org/state-solar-policy/south-car olina. Accessed 31 July 2016

U.S. Cover Note INCD and Accompanying Information (2015) Retrieved from http://grist.org/news/if-the-epa-relaxes-deadlinesfor-co2-cuts-will-the-u-s-still-be-able-to-keep-its-climate-promises/ Inpapers3://publication/uuid/CC9150F0-64D1-449F-9BE5-EC6E4 B2AD66E. Accessed 1 August 2016

U.S. Energy Information Administration (EIA) (2016) Electric power monthly with data for May 2016 https://www.eia.gov/electricity/ monthly/pdf/epm.pdf. Accessed 29 July 2016

USGS Land Cover Institute (2012) NLCD 92 Land cover class definitions. http://landcover.usgs.gov/classes.php. Accessed 12 March 2016 